The Chittagong Univ. J. B. Sci., Vol. 6(1 \&2):51-63, 2011.

\title{
ASSESSMENT OF GENETIC DIVERSITY AND RELATIONSHIP AMONG SOME COMMERCIAL CUCUMBER VARIETIES AND GENOTYPES USING RAPD MARKERS
}

\author{
S.M.FAISAL ${ }^{1}$, M.S.HAQUE ${ }^{2}$, K.M.NASIRUDDIN ${ }^{2}$, M.M.ISLAM ${ }^{3}$, M.ASHRAFUZZAMAN $^{4}$ \\ AND M.A.ALI ${ }^{5}$ \\ ${ }^{1}$ Horticulture Division, Regional Agricultural Research Station, BARI, Hathazari, Chittagong; \\ ${ }^{2}$ Dept. of Biotechnology, Faculty of Agriculture, Bangladesh Agricultural University, \\ Mymensingh-2202; \\ ${ }^{3}$ Plant Breeding Division, Bangladesh Institute of Nuclear Agriculture, Mymensingh-2202; \\ ${ }^{4}$ Dept. of Genetic Engineering \& Biotechnology, School of Life Sciences, Shahjalal University of \\ Science \& Technology, Sylhet-3114 and \\ ${ }^{5}$ Upazilla Agriculture Office, Kishorganj, Nilphamari, Bangladesh.
}

\begin{abstract}
Genetic variability among the genotypes of any species could be utilized for its improvement. PCR-based Random Amplified Polymorphic DNA (RAPD) technique was used to determine the genetic diversity and relationship among 10 cucumber varieties and genotypes. Five decamer primers were used to amplify genomic DNA and the primers yielded a total of 54 bands of which 36 bands were polymorphic and 18 bands were monomorphic. The UPGMA dendrogram based on Nei's (1972) genetic distance indicated segregation of 10 cucumber varieties and genotypes into two main clusters. Variety Joti alone grouped in cluster 1 while variety Green Master, Shahi-50, Shikha, Shila, Shital, Naogaon-5, Shohag-50, Giant Long and genotype CS-043 grouped in cluster 2. Variety Shila was very close to variety Shital with the least genetic distance (0.1712). The highest genetic distance (0.5352) was found between Joti and Naogaon-5.
\end{abstract}

Key words: Genetic distance, polymorphism, PCR, dendrogram, cucumber.

\section{INTRODUCTION}

Cucumber (Cucumis sativus L.) $(2 \mathrm{n}=14)$, a member of the family Cucurbitaceae, is one of the oldest vegetable crop supposed to be originated in India, between the Bay of Bengal and the Himalayas (Peirce 1987). It has been known in the history for over 3000 years. Cucumis sativus L. is one cucumber species which has commercial importance (Nonnecki 1989).

*Corresponding Author:osru2002@yahoo.com 
Plant genetic diversity is a key component of any agricultural production system. This genetic diversity or similarity can be measured through genetic markers. These have been used to determine evolutionary relationship within and between species, genera or higher taxonomic categories (Paterson et al. 1991). The analysis of genetic diversity and relatedness between or within different species, populations and individuals is a prerequisite towards effective utilization and protection of plant genetic resources (Weising et al. 1995). In Bangladesh, there are lot of variability among cucumber germplasms. Some of these germplasms might have resistance to biotic and abiotic stresses that would be utilized in breeding program by traditional as well as modern techniques like Agrobacterium - mediated gene transfer. So, there are promising scopes to utilize these variability for improvement of this crop. The basis of the RAPD method is to use PCR with short oligonucleotide primers of arbitrary (random) sequence to generate genetic markers. Because RAPD-PCR primers are not designed to amplify a specific target sequence, the amplified loci are anonymous and

presumably scattered throughout the genome (Williams et al. 1990). RAPD analysis is advantageous over isozyme electrophoresis because it generates much greater number of loci required for genetic analysis (Kimberling et al., 1996). RAPD markers can be used as supposedly unbiased and neutral markers for genetic mapping applications (Michelmore et al. 1991), taxonomy (Chapco et al. 1992) as well as for genetic diagnostics. To attain this aim, the present study was carried out with the objective to asses the genetic diversity at the level of nuclear DNA and to establish a relationship among ten cucumber varieties and genotypes.

\section{MATERIALS AND METHODS}

\section{Plant materials}

The investigation was carried out at the Biotechnology Laboratory under the division of Plant Breeding, Bangladesh Institute of Nuclear Agriculture (BINA), Mymensingh during June, 2005 to July, 2009. Ten cucumber genotypes were used in the present investigation which had diverse genetic background. There were nine varieties collected from local seed market and one advanced line collected from the Department of Horticulture, Bangladesh Agricultural University (BAU), Mymensingh (Table 1).

TABLE 1: LIST OF CUCUMBER VARIETIES AND GENOTYPES USED IN THE STUDY

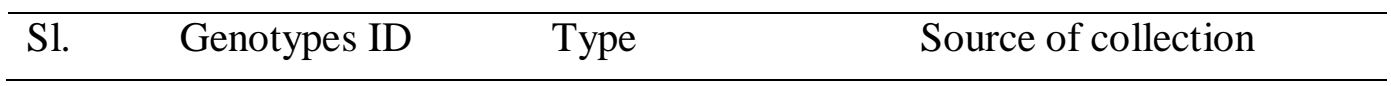


ASSESSMENT OF GENETIC DIVERSITY AND RELATIONSHIP AMONG SOME COMMERCIAL CUCUMBER VARIETIES AND GENOTYPES USING RAPD MARKERS

\begin{tabular}{llll}
\hline 1 & Shahi-50 & HYV & Metal Agro Limited \\
2 & Shila & HYV & East-West Seed Co. \\
3 & Shital & HYV & Namdhari Malik Seed Co. \\
4 & Naogaon-5 & HYV & Metal Agro Limited \\
5 & Shoag-50 & HYV & Metal Agro Limited \\
6 & Jiant Long & HYV & Metal Agro Limited \\
7 & Shikha & HYV & United Seed Store \\
8 & Green Master & HYV & United Seed Store \\
9 & CS-043 & Advance line & Dept. of Horticulture, \\
10 & Joti & HYV & Energypac Agro Ltd. \\
\hline
\end{tabular}

Genotyping of cucumber genotypes

DNA extraction was done by using the mini preparation modified CTAB method (IRRI, 1997). DNA samples were evaluated both quantitatively and qualitatively using spectrophotometer and $\lambda$ (lambda) DNA (concentration marker), respectively. Each RAPD reaction was done in a volume of $10 \mu \mathrm{l}$ containing 10X PCR buffer $1 \mu \mathrm{l}, 250 \mu \mathrm{M}$ dNTP (mix) $1 \mu \mathrm{l}, 10 \mu \mathrm{M}$ primer $2.5 \mu \mathrm{l}$, $25 \mathrm{ng} / \mu \mathrm{l}$ DNA template $2 \mu \mathrm{l}$, Taq DNA polymerase 1 unit or $0.2 \mu \mathrm{l}$ and sterile deionized water $3.3 \mu$ l. DNA amplification was performed in an oil-free thermal cycler with the following program : initial denaturation at $94^{\circ} \mathrm{C}$ for $3 \mathrm{~min}$ followed by 40 cycles of $30 \mathrm{sec}$ denaturation at $94^{\circ} \mathrm{C}, 30 \mathrm{sec}$ annealing at $37^{\circ} \mathrm{C}$ and primer elongation or extension at $72^{\circ} \mathrm{C}$ for $2 \mathrm{~min}$. After the last cycle, a final step for 7 minutes at $72^{\circ} \mathrm{C}$ was allow to complete extension of all amplified fragments. After completion of cycling program, reactions were held at $4^{\circ} \mathrm{C}$. The amplified products were separated by electrophoresis in $1.5 \%$ agarose gel. After electrophoresis, the gel was stained for 20 minutes in ethidium bromide solution. DNA bands were observed under UV light on a transilluminator and photographed. Seven primers 63AB10A3, 68AB10A8, 62AB10C2, 69AB10C9, $70 \mathrm{AB} 10 \mathrm{C} 10,61 \mathrm{AB} 10 \mathrm{G} 1$ and $64 \mathrm{AB} 10 \mathrm{G} 4$ of random sequence were screened on two different genotypes to evaluate their suitability.

\section{RAPD data analysis}

The amplified bands were visually scored on the basis of their presence (1) or absence (0), separately for each individual and each primer. The scores obtained using all primers in the RAPD analysis were then pooled to create a single data matrix. This was used to estimate polymorphic loci, Nei's (1973) gene diversity, genetic distance (D) and to construct a UPGMA (Unweighted Pair Group Method With Arithmetic Means) dendrogram among populations using 
FAISAL et al.

computer program, POPGENE (Version 1.31) (Yeh, et al., 1999). The same program was also used to perform the test of homogeneity in different locus between population pairs.

\section{RESULTS AND DISCUSSION}

Primer selection and RAPD pattern

Out of seven decamer primers five primers i.e. 63ABIOA3, 68AB10A8, 62AB10C2, 69AB10C9 and 61AB10GI which gave reproducible and distinct polymorphic amplified products were selected. Selected five primers exposed 54 bands. Out of 54 bands, 36 bands (66.67\%) were polymorphic and 18 bands $(33.33 \%)$ were monomorphic (Table 2). In an investigation of cucumber, Joyanti (2007) obtained $95.64 \%$ polymorphic bands from big cucumber group (sosha) and $88.64 \%$ polymorphic bands from small cucumber group (khira) using the same DNA primers. Five different primers generated various banding patterns, ranging from 10 (68 $\mathrm{AB} 10 \mathrm{~A} 8$ and $61 \mathrm{AB} 10 \mathrm{G} 1)$ to 12 (69AB10C9). The primer 69AB10C9 generated the highest number of polymorphic bands (11). Thus it showed a higher level of polymorphism. On the other hand, the primer $68 \mathrm{AB} 10 \mathrm{~A} 8$ and $62 \mathrm{AB} 10 \mathrm{C} 2$ produced the lowest number (4) of polymorphic bands (Table 2).

TABLE 2: RAPD PRIMERS WITH THEIR CORRESPONDING POLYMORPHIC BANDS OBSERVED IN CUCUMBER GERMPLASMS

\begin{tabular}{llccc}
\hline Primer codes & Sequences $\left(5^{\prime}-3^{\prime}\right)$ & $\begin{array}{c}\text { Number of } \\
\text { bands }\end{array}$ & $\begin{array}{c}\text { Number of } \\
\text { polymorphic bands }\end{array}$ & $\begin{array}{c}\text { Polymorphic } \\
\text { loci (\%) }\end{array}$ \\
\hline 63AB10A3 & GTCGCCGTCA & 11 & 9 & \\
68AB10A8 & GTGTGCCCCA & 10 & 4 & \\
62AB10C2 & GGACCCAACC & 11 & 4 & \multirow{2}{*}{66.67} \\
69AB10C9 & CTCTGGAGAC & 12 & 11 & \\
61AB10G1 & ACCGCGAAGG & 10 & 8 & \\
\cline { 1 - 3 } Total & - & 54 & 36 & \\
\hline Average & - & 10.8 & 7.2 & \\
\hline
\end{tabular}

The banding patterns of different cucumber varieties and genotypes using primers $63 \mathrm{AB} 10 \mathrm{~A} 3$ and 68AB10A8 are shown in Figures 1 and 2, respectively. On an average each primer generated 10.8 scorable bands and 7.2 polymorphic bands per primer. Dark and light bands were produced from the RAPD reactions. Light bands produced from low homology between the primer and the pairing site 
ASSESSMENT OF GENETIC DIVERSITY AND RELATIONSHIP AMONG SOME COMMERCIAL CUCUMBER VARIETIES AND GENOTYPES USING RAPD MARKERS

on the DNA strand (Thormann et al., 1994). In present investigation, the percentage of polymorphic loci was $66.67 \%$. A diverse level of polymorphism in different crops has been reported by Ashrafuzzaman (2007) (95.64 \% in rice), Moonmoon (2006) (90.19 \% in tomato) and Joyanti (2007) (95.64 \% and 88.64 $\%$, respectively in large and small group cucumber).

\section{Polymorphism and Nei's gene diversity}

The highest percentage polymorphic loci $(18.52 \%)$ was found in Naogaon-5 which gave 10 polymorphic loci whereas the lowest percentage (11.11\%) polymorphic loci were observed both in Shahi-50 and Shital which gave 6 polymorphic loci (Table 3). The variety Naogaon-5 showed the higher level of gene diversity (0.0904) than that of other tested varieties and genotypes. Gene diversity (h) across all varieties and genotypes for all loci was 0.6834. Shahi-50 showed the lowest (0.0507) gene diversity. Shannon's information index (I) of all cucumber varieties and genotypes was 0.9548 . The highest and the lowest I value were observed in variety Naogaon-5 (0.1261) and Shahi-50 (0.0719), respectively (Table 3). Since the variety Naogaon-5 exhibited the highest percentage polymorphic loci, gene diversity and shannon's information index, these suggested higher polymorphism. The above results indicated that plant breeder could utilize this variety (Naogaon-5) for breeding program. Estimation of Nei's (1973) genetic diversity and Shannon's information index across all loci supports the existence of high level of genetic variations among 10 cucumber varieties and genotypes.

\section{Intra and inter genotype similarity indices}

Intra genotype similarity indices $\left(\mathrm{S}_{\mathrm{i}}\right)$ were higher ranging from 88.00 to $93.80 \%$ with an average of $91.54 \%$ than inter variety similarity indices (Sij) ranging from 57.20 to $86.80 \%$ with an average of $71.48 \%$. The highest intra genotype similarity indices $\left(\mathrm{S}_{\mathrm{i}}\right)$ were observed both in Shahi-50 and CS-043 $(93.80 \%)$, and the lowest intra genotype similarity indices was found in Shikha

$(88.00 \%)$. The highest inter genotype similarity indices (Sij) was found between Shila and Shital $(86.80 \%)$ and the lowest inter genotype similarity indices or band sharing value was observed between Naogaon-5 and Joti $(57.20 \%)$.

TABLE 3: ESTIMATION OF GENETIC VARIATION, PERCENTAGE OF POLYMORPHIC LOCI, NEI'S (1973) GENE DIVERSITY (H), AND $\begin{array}{llllll}\text { SHANNON'S INFORMATION INDEX } & \text { (I) OBTAINED } & \text { FROM } & 10\end{array}$ CUCUMBER VARIETIES AND GENOTYPES 
FAISAL et al.

\begin{tabular}{lcccc}
\hline \multicolumn{1}{c}{ Genotype } & $\begin{array}{c}\text { Number of } \\
\text { polymorphic } \\
\text { loci }\end{array}$ & $\begin{array}{c}\text { Percentage of } \\
\text { polymorphic } \\
\text { loci }\end{array}$ & $\begin{array}{c}\text { Gene } \\
\text { diversity } \\
\text { (h) }\end{array}$ & $\begin{array}{c}\text { Shannon's } \\
\text { Information index } \\
\text { (I) }\end{array}$ \\
\hline Shahi-50 & 6 & 11.11 & 0.0507 & 0.0719 \\
Shila & 7 & 12.96 & 0.0633 & 0.0883 \\
Shital & 6 & 11.11 & 0.0542 & 0.0757 \\
Naogaon-5 & 10 & 18.52 & 0.0904 & 0.1261 \\
Shohag-50 & 8 & 14.81 & 0.0723 & 0.1009 \\
Giant long & 7 & 12.96 & 0.0633 & 0.0883 \\
Shikha & 8 & 14.81 & 0.0723 & 0.1009 \\
Green Master & 8 & 14.81 & 0.0723 & 0.1009 \\
CS-043 & 7 & 12.96 & 0.0633 & 0.0883 \\
Joti & 9 & 16.67 & 0.0813 & 0.1135 \\
\hline Total & - & - & 0.6834 & 0.9548 \\
\hline
\end{tabular}

Gene flow and population differentiation

The average estimated gene flow $(\mathrm{Nm})$ was 0.1386 and co-efficient of gene differentiation (Gst) was 0.7830 across all primers. Random amplified polymorphic DNA marker 68AB10A8 showed low level of differentiation (Gst) $(0.3533)$ in the studied varieties and genotypes.

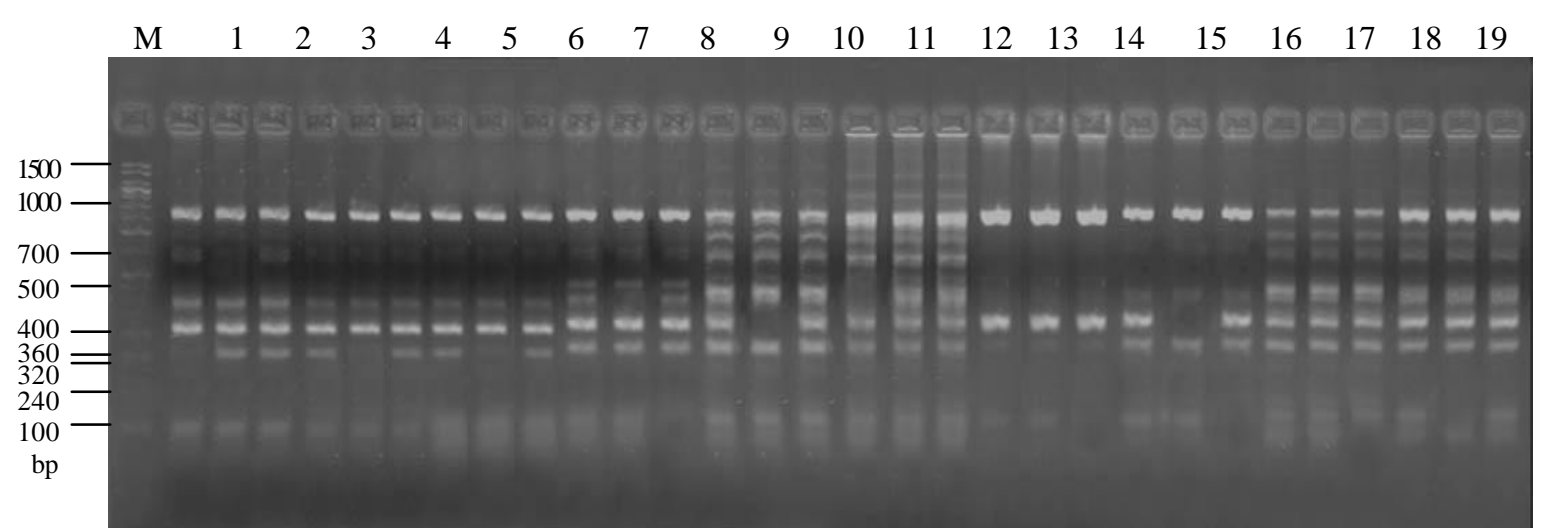


ASSESSMENT OF GENETIC DIVERSITY AND RELATIONSHIP AMONG SOME COMMERCIAL CUCUMBER VARIETIES AND GENOTYPES USING RAPD MARKERS

FIG. 1. RAPD PROFILES OF 10 CUCUMBER GERMPLASMS USING PRIMER 63AB10A3. LANE 1-3: SHAHI-50, 4-6: SHILA, 7-9: SHITAL, 10-12: NAOGAON-5, 13-15: SHOHAGH50, 16-18: GIANT LONG, 19-21: SHIKHA, 22-24: GREEN MASTER, 25-27: CS-043, 28-30: JOTI. M: MOLECULAR WEIGHT MARKER (20 BP DNA LADDER)

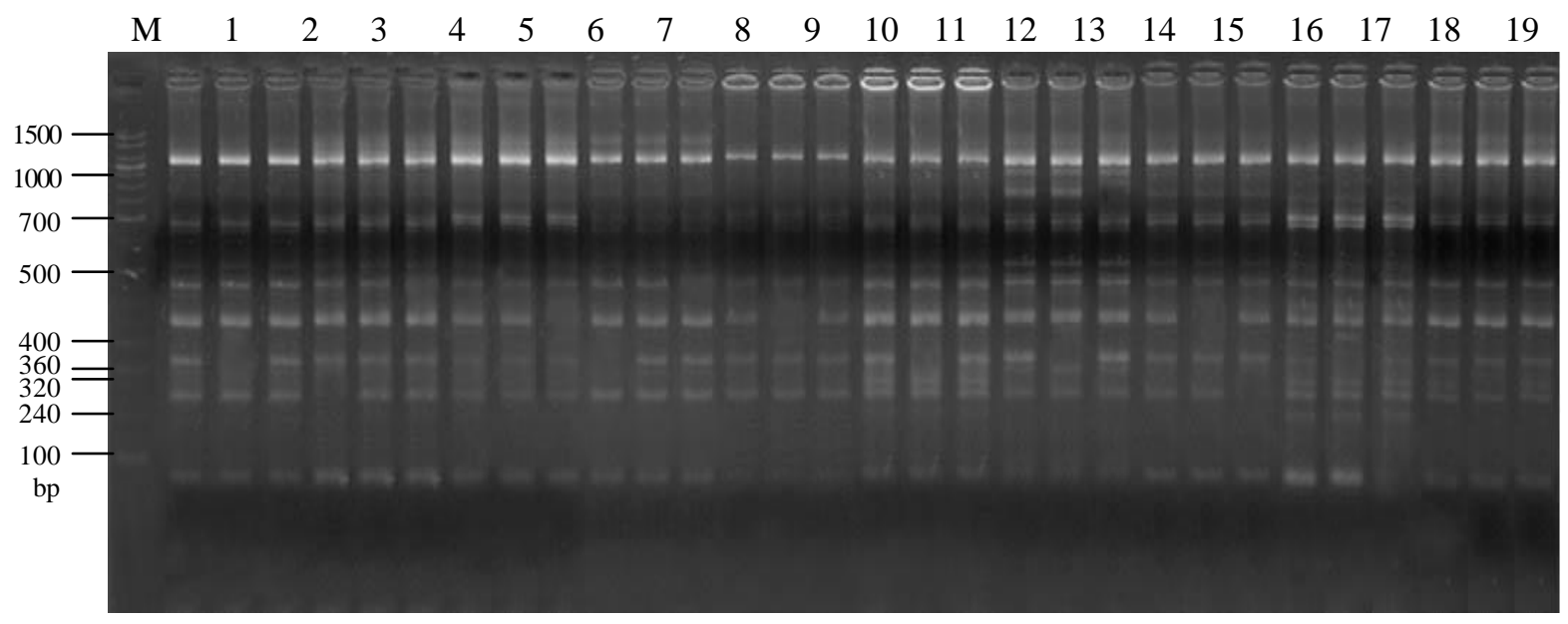

FIG. 2. RAPD PROFILES OF 10 CUCUMBER GERMPLASMS USING PRIMER 68AB10A8. LANE 1-3: SHAHI-50, 4-6: SHILA, 7-9: SHITAL, 10-12: NAOGAON-5, 13-15: SHOHAGH50, 16-18: GIANT LONG, 19-21: SHIKHA, 22-24: GREEN MASTER, 25-27: CS-043, 28-30: JOTI.M: MOLECULAR WEIGHT MARKER (20 BP DNA LADDER)

Genetic distance

The values of pair-wise comparisons of Nei's (1972) genetic distance (GD) among 10 cucumber varieties and genotypes computed from combined data from the five primers ranged from 0.1712 to 0.5352 (Table 4). The 
highest genetic distance (0.5352) was found between variety Joti and Naogaon-5 and the lowest (0.1712) GD was observed between variety Shital and Shila. From the difference between the highest and the lowest GD value it was revealed that there were wide variabilites among 10 cucumber varieties and genotypes. Mliki et al. (2003) reported different GD of 3 groups of African cucumber accessions. They mentioned that GD of group 1 ranged between 0.52 to 0.90, distances among group 2 accessions varied between 0.93 to 0.97 and the GD in group 3 was 0.65 . Joyanti (2007) found GD ranged between 0.04 to 0.788 in sosha (large cucumber group) and GD ranged from 0.023 to 0.83 in Khira (small cucumber group). High genetic variability within varieties and significant difference between varieties indicate rich genetic material of a species. This study indicated that variety Joti and Naogaon-5 showed the highest genetic variation, while the lowest genetic variation was observed between variety Shital and Shila, which can be used as parental source for breeding line to improve cucumber varieties. Moonmoon (2006) reported that for the assessment of genetic diversity, molecular markers were superior to morphological, biochemical and other method like pedigree and heterosis.

\section{UPGMA dendrogram}

Dendrogram based on Nei's (1972) genetic distance using Unweighted Pair Group Method with Arithmetic Means (UPGMA) indicated segregation of ten cucumber varieties and genotypes into two main clusters. Variety Joti alone formed cluster 1 and variety Green Master, Shahi-50, Shikha, Shila, Shital, Naogaon-5, Shohag-50, Giant Long and the genotype CS-043 grouped in cluster 2 (Fig. 3). In cluster 2 variety Green Master, Shahi-50, Shika, Shila, Shital, Naogaon-5 and Shohag-50 formed sub cluster-1 and variety Giant Long and genotype CS-043 formed sub cluster-2. Again in sub cluster-1 variety Green Master, Shahi-50 and Shikha formed sub sub cluster-1, and variety Shila, Shital, Naogaon-5 and Shohag-50 formed sub sub cluster-2. Again in sub sub cluster-1, variety Green Master alone formed group 1 and variety shahi-50 and shikha formed group 2, respectively and in sub sub cluster-2, variety Shila and Shital formed group 3 and variety

TABLE 4: SUMMARY OF NEI'S (1972) GENETIC DISTANCE (BELOW DIAGONAL) VALUES AMONG 10 CUCUMBER VARIETIES AND GENOTYPES

\begin{tabular}{lllllllll}
\hline Genotype & Shahi- & Shila & Shital Naogaon-5 Shohag-50 Giant & Shikha & Green & CS- Joti \\
\hline
\end{tabular}




\begin{tabular}{|c|c|c|c|c|c|c|c|c|c|c|}
\hline & 50 & & & & & Long & & Master & 043 & \\
\hline Shahi-50 & $* * * *$ & & & & & & & & & \\
\hline Shila & 0.2148 & $* * * *$ & & & & & & & & \\
\hline Shital & 0.2633 & 0.1712 & $* * * *$ & & & & & & & \\
\hline Naogaon-5 & 0.3156 & 0.2334 & 0.2231 & $* * * *$ & & & & & & \\
\hline Shohag-50 & 0.3239 & 0.4128 & 0.2126 & 0.2045 & $* * * *$ & & & & & \\
\hline Giant Long & 0.4285 & 0.4103 & 0.5278 & 0.3930 & 0.3877 & $* * * *$ & & & & \\
\hline Shikha & 0.2052 & 0.2609 & 0.3816 & 0.4993 & 0.3878 & 0.3042 & $* * * *$ & & & \\
\hline $\begin{array}{l}\text { Green } \\
\text { Master }\end{array}$ & 0.2723 & 0.2636 & 0.2970 & 0.3855 & 0.3559 & 0.3401 & 0.2525 & $* * * *$ & & \\
\hline CS-043 & 0.3727 & 0.4774 & 0.5117 & 0.4184 & 0.3684 & 0.2170 & 0.2735 & 0.3501 & $* * * *$ & \\
\hline Joti & 0.3549 & 0.3974 & 0.4446 & 0.5352 & 0.3985 & 0.4784 & 0.4657 & 0.4138 & 0.4884 & $* * * *$ \\
\hline
\end{tabular}

Naogaon-5 and Shohag-50 formed group-4, respectively. Variety Shila was closer to the variety Shital with the least GD (0.1712), so they fall under group 3 and the highest GD (0.5352) was found among Joti and rest of the varieties and genotypes. That's why Joti alone formed one cluster and rest of varieties and genotypes formed another cluster. Except variety Joti other varieties and genotypes fall under cluster 2. These varieties and genotypes were probably identical based on some morphological characters. Variety Green Master, Shahi50, Shikha, Shila, Shital, Naogaon-5 and Shohag-50 formed sub cluster-1, so that they were maintaining the closest genetic relationship. Similarly variety Giant Long and genotype CS-043 formed sub cluster-2, so that they had also close genetic relationship. In an investigation of molecular characterization of cucumber through RAPD maker Joyanti (2007) reported that two types of cucumber namely sosha (large cucumber group) and khira (small cucumber group) formed two different dendrogram. Regarding sosha germplasms, they were distinctly divided 
into two major clusters A and B. Cluster A comprised the largest number (16) of germplasms and the rest formed cluster B. On the other hand, khira germplasms also divided into two major clusters. Mliki et al. (2003) arranged 26 African cucumber germplasms into 3 major groups. Group 1 consisted of 21 accessions (Egypt, Ethiopia and Libya), group 2 consisted of two accessions (Kenya and Algeria) and group 3 possessed three accessions (Egypt). These groups were different from each other $(\mathrm{P}>0.001)$. Accessions in group 1 differed genetically from all other accessions examined (P>0.01) and accessions of group 2 and 3 were uniquely associated with several RA accessions. In an investigation, Zhang et al. (1998) classified 34 cucumber germplasms into 3 groups viz. China group, South China group and European greenhouse group. From this investigation, it was revealed that the highest genetic diversity remains between variety Joti and Naogaon-5. On the other hand, the lowest genetic diversity was observed between the variety Shila and Shital. These findings indicated that variety Joti vs variety Naogaon-5 and variety Shila vs variety Shital could be used in plant breeding program for development of cucumber variety. RAPD markers provide a fast and efficient tool for genetic variability assessment and currently using in plant genetic resources management.

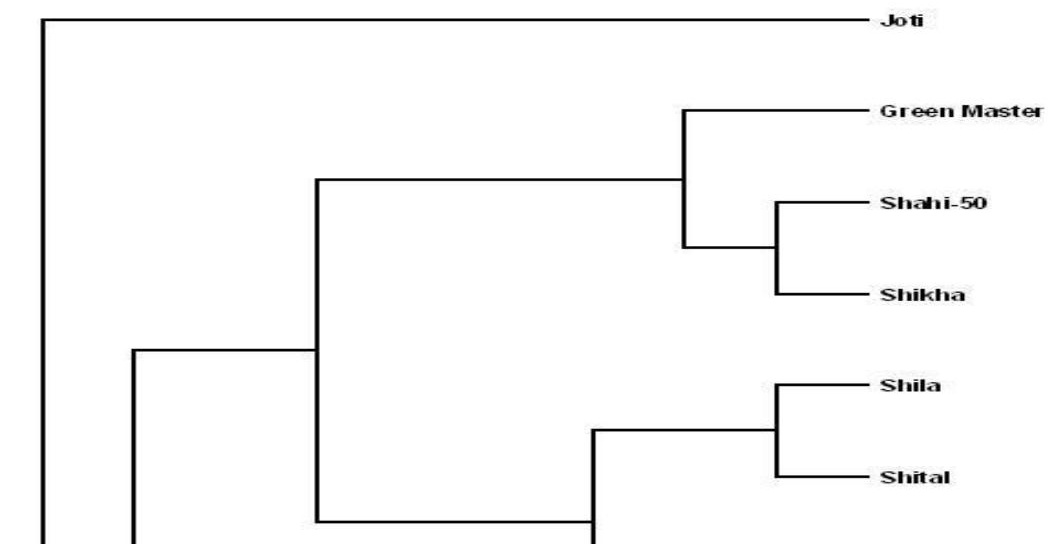


ASSESSMENT OF GENETIC DIVERSITY AND RELATIONSHIP AMONG SOME

COMMERCIAL CUCUMBER VARIETIES AND GENOTYPES USING RAPD MARKERS

FIG. 3. UPGMA DENDROGRAM BASED ON NEI'S (1972) GENETIC DISTANCE SUMMARIZING THE DATA ON DIFFERENTIATION AMONG TEN CUCUMBER VARIETIES AND GENOTYPES, ACCORDING TO RAPD ANALYSIS

\section{Acknowledgements}

The author is grateful to BARI and the Ministry of Science and Information and Communication Technology of the Government of Bangladesh for providing financial support during Ph.D. study.

\section{REFERENCES}

ASHRAFUZZAMAN, M. 2007. Genetic diversity analysis of rice genotypes as revealed by RAPD markers. MS thesis. Dept. of Biotechnology. Bangladesh Agricultural University, Mymensingh, pp. 16-50.

CHAPCO, W., ASHTON, N. W., MARTEL, R. K., ANTONISHISHYN, N. AND CROSBY, W. L. 1992. A feasibility study of the use of 
random amplified polymorphic DNA in the population genetics and systematic of grasshoppers. Genome. 35: 569-574.

IRRI. 1997. IRRI discussion paper series no. 22. P.O.Box 933, Manila 1099, Philippines. 3 pp

JOYANTI, D. 2007. Molecular characterization of forty eight cucumber germplasm using RAPD. MS thesis. Dept. of Horticulture. Bangladesh Agricultural University, Mymensingh, pp. 30-53.

KIMBERLING, D. N, FERREIRA, A. R., SHUSTER, S. M. AND KEIM, P. 1996. RAPD marker estimation of genetic structure among isolated northern leopard frog populations in the south-western USA. Mol. Ecol. 5: 521-529.

MICHELMORE, R. W., PARAN, I. AND KESSELI, R. V. 1991. Identification of markers linked to disease-resistance genes by bulked segregant analysis: a rapid method to detect markers in specific genomic regions by using segregating populations. Proc. Natl. Acad. Sci. U.S.A. 88: $9828-9832$.

MLIKI, A., STAUB, J. E., ZHANGYONG, S. AND GHORBEL, A. 2003. Genetic diversity in African cucumber (Cucumis sativus L.) provides potential for germplasm enhancement. Genetic resources and crop evolution. 50 (5): 461-468.

MOONMOON, S. 2006. Random Amplified Polymorphic DNA markers (RAPD) for genetic variation study among tomato varieties. MS thesis. Dept. of Biotechnology. Bangladesh Agricultural University, Mymensingh, pp. 34-51.

NEI, M. 1972. Genetic distance between populations. American Naturalist. 106: 283-292.

NEI, M. 1973. Analysis of gene diversity in subdivided populations. Proc. Natl. Acad. Sci. U.S.A. 70: 3321-3323.

NONNECKI, I. L. 1989. Vegetable Production.. An AVI book, Van Nostrand Reinhold, 115 Fifth Avenue, New York 10003, USA, pp. 509-526.

PATERSON, A. H., Tanksley, S. D. and Sorrells, M. E. 1991. DNA markers in plant improvement. Adv. Agron. 46: 39-90.

PEIRCE, L. C. 1987. Vegetables: characteristics, production and marketing. John Wiley and Sons, USA, pp. 357-366.

THORMANN, C. E., FERREIRA, M. E., CAMARGO, L. E.A., TIVANG, J. G. AND OSBORN, T. C.1994. Comparison of RFLP and RAPD markers for estimating genetic relationships within and among cruciferous species. Theor. Appl. Genet. 88: 973-980. 
ASSESSMENT OF GENETIC DIVERSITY AND RELATIONSHIP AMONG SOME

COMMERCIAL CUCUMBER VARIETIES AND GENOTYPES USING RAPD MARKERS

WEISING, K., ATKINSON, G. AND GARDNER, C. 1995. Genomic fingerprinting by microsatellite-primed PCR: a critical evaluation. PCR Methods Applications. 4: 249-255.

WILLIAMS, J. G. K, KUBELIK, A. R., LIVAK, K. J., RAFALSKI, J. A. AND TINGEY, S. V. 1990. DNA polymorphisms amplified by arbitrary primers are useful as genetic markers. Nucleic Acids Res. 18(22): 6531-6535.

YEH, F. C., YANG, R. C., BOYLE, T. B. J, YE, Z. H. AND MAO, J. X. 1999. POPGENE, the user-friendly software for population genetic analysis. Mol. Biol. And Biotech. Cent., Univ. of Alberta, Canada.

ZHANG, H. Y., WANG, Y. J., XU, Y., QUYANG, X. X. AND KANG, G. B. 1998. RAPD used in analysis of genetic relationships of cucumber (Cucumis sativus L.) germplasm. Acta Horticulture Sinica. 25(4): 345-349.

Manuscript received on 03.05.2011; Accepted on 07.07.2012

The Chittagong University Journal of Biological Sciences, Vol. $6(1$ \& 2). Page No. 